\title{
Identification of Problems and Needs of Professional Development of Special Education Teacher in Inclusive School
}

${ }^{1 s t}$ Munawir Yusuf

Special Education Department, Faculty of Teacher Training and Education,Universitas Sebelas Maret, Surakarta, Indonesia munawiruns@yahoo.co.id 2nd Erma Kumala Sari

Special Education Department, Faculty of Teacher Training and Education, Universitas Sebelas Maret, Surakarta, Indonesia 3rd ArsyAnggrellanggi

Special Education Department, Faculty of Teacher Training and Education, Universitas Sebelas Maret, Surakarta, Indonesia

\begin{abstract}
This study aims to identify the problems and needs of professional development of special education teacher (SET) in inclusive schools. This research is a survey research with quantitative approach. The research respondents consisted of 265 special education teachers in $\mathbf{2 4 2}$ inclusive schools in Central Java Indonesia. The research data was collected with questionnaire on the problems and needs of SET professional development in inclusive schools, consisting of 4 domains, namely (1) SET competence development, (2) SET performance appraisal, (3) SET work award, 4) SET career development. Data analysis technique used is descriptive statistical analysis. The result of the study shows that SET profession in inclusive schools in Indonesia still faces many problems and the level of requirement to get SET professional development tends to be high and very high. Thus, a clear program and a standard regulation regarding SET professional development are required.
\end{abstract}

Keywords- problems; needs; professional development; special education teacher; inclusive school

\section{INTRODUCTION}

Many research in the world focuses on special education teachers (Johnson, E. \&Semmelroth, C. L., 2013; Jones, N. D. \&Brownell, M. T., 2013; McCall, Z., McHatton, P. A., \&Shealey, M. W., 2013; Sledge, A. \&Pazey, B. L., 2013; Vernon-Dotson, L. J., Floyd, L. O., Dukes, C., \&Darling, S. M., 2013; Woolf, S. B., 2014; Douglas, S. N.; Chapin, S. E.; Nolan, J. F., 2016). Meanwhile, research on special education teachers has also been conducted in Indonesia by several researchers (Gunarhadi, Sunardi, Andayani, T.R., \& Anwar, M., 2016; Gunarhadi, Sugini, \&Andayani, T.R., 2012).

Special education teachers in inclusive schools are special education teachers who guide special needs children in inclusive schools. National Education Ministerial Regulation No. 70/2009 explains that each inclusive school must have at least one special education teacher. This regulation shows that the presence of SET in inclusive schools is important to note. Thus, SET in inclusive schools becomes an important profession as well as regular teachers.
However, the SET profession in inclusive schools still encounters many problems. Billingsley, B. S. (2004) explains that there are SET problems in terms of SET shortages, low qualifications and competencies of SET, uncertified SETs, and attrition of SETs. Those problems will affect the professionalism of the SET profession so that it will affect the quality of children with special needs education (Billingsley, B. S., 2004).

Therefore, SET requires clear regulation related to the existence of the profession just like any other regular teacher so that professionality of SET as a profession in inclusive schools can be maintained.However, there is no clear regulation governing SET professional development in inclusive schools in Indonesia. Meanwhile, Dudzinski, M., Roszmann-Millican, M., \&Sbank, K. (2000) explained that the issues to be considered in SET professional development are SET performance standards, license and certification of SET, and the need for competence development and career development. Therefore, this study aims to identify problems and needs of SET professional development in inclusive schools in Indonesia, related to competence development, performance appraisal, work award, and career development.

\section{METHOD}

This research is a survey research with quantitative approach. The subjects of the research consisted of 265 special education teachers in 242 inclusive schools in Central Java Indonesia. This study examines the problems and needs of SET professional development in inclusive schools in Indonesia, with 4 domains: (1) SET competence development, (2) SET performance appraisal, (3) SET work award, and (4) SET career development. The research data were collected with questionnaire on the issues and the need for SET professional development in inclusive schools. Data analysis technique used is descriptive statistical analysis. 
TABLE 1. The form of SET competence development

\begin{tabular}{lcc}
\hline $\begin{array}{l}\text { Forms of SET Competence } \\
\text { Development }\end{array}$ & Total & $\begin{array}{c}\text { Percentage } \\
(\boldsymbol{\%})\end{array}$ \\
\hline Training/Upgrading/Workshop & 201 & 75.8 \\
Comparative study & 17 & 6.4 \\
Internships & 4 & 1.5 \\
Scholarship & 1 & 0.4 \\
Others & 40 & 22.7 \\
\hline
\end{tabular}

\section{RESULTS}

\section{Problems of SET Professional Development}

The results show that SET career in Indonesia as a profession in inclusive schools still encounters various problems. These problems are described in more detail as follows.

\section{Competence Development of SET}

The government has tried to develop for the competence of SET in inclusive schools through various programs. The form of competence development of SET includes training, upgrading, workshop, apprenticeship, comparative study, and socialization.
Table 3 shows the SET response to the competence development that has been conducted by government. It appears that most respondents $(72.8 \%)$ felt that the programs had not fulfilled their needs and only around $27.2 \%$ of SET felt that the programs had fulfilled their needs. It indicates that the SET competence development program has not been based on SET need assessment, but rather based on 'top down' program.

\section{Performance Appraisal of SET}

Problems related to SET performance appraisal is there is no standard appraisal of SET performance, whether related to the time period and aspects of appraisal. The research found that $51.3 \%$ of SET were assessed for their performance by superiors (principals), while 44.5\% were never assessed. Furthermore, there is a various time period of SET performance appraisals, which are once a year (19.6\%), twice a year $(16.6 \%)$ and more than twice a year $(63.8 \%)$. Meanwhile, the parties who conduct the SET performance appraisal also vary.

TABLE 4. The executor of SET performanceappraisal

Table 1 shows the form of competence development of SET in inclusive schools. The form of SET competence developmentthat has been done by the government, include training/upgrading/workshop (75.8\%), comparative study followed $(6.4 \%)$, internship (1.5\%), provision of scholarships $(0.4 \%)$ and get coaching in other forms $(22.7 \%)$.

TABLE 2. The executor of SET competence development

\begin{tabular}{lcc}
\hline $\begin{array}{l}\text { Executor of SET Competence } \\
\text { Development }\end{array}$ & Total & $\begin{array}{c}\text { Percentage } \\
(\boldsymbol{\%})\end{array}$ \\
\hline Central government & 16 & 6.0 \\
Provincial government & 26 & 9.8 \\
District/city government & 178 & 67.2 \\
School & 26 & 9.8 \\
Others & 65 & 24.5 \\
\hline
\end{tabular}

Table 2 shows of SET competence development from various institutions.Based on table 2 shows that the District/City government has a big role $(67.2 \%)$ in conducting competence development of SET. The rest SET competence development comes from the central government, provincial government, schools, and others.

TABLE 3. The SET responds of SET competence development program

\begin{tabular}{lcc}
\hline SET Response & Total & Percentage (\%) \\
\hline Already meet the & & \\
needs & 72 & 27.2 \\
Not meeting the needs & 157 & 72.8 \\
\hline
\end{tabular}

\begin{tabular}{lcc}
\hline $\begin{array}{l}\text { Executor of SET } \\
\text { PerformanceAppraisal }\end{array}$ & Total & $\begin{array}{c}\text { Percentage } \\
(\%)\end{array}$ \\
\hline Local service & 5 & 1.9 \\
Headmaster & 116 & 43.8 \\
Supervisor & 4 & 1.5 \\
Not knowing & 140 & 52.9 \\
\hline
\end{tabular}

Based on table 4, it appears that $52.9 \%$ of SET answered did not know the party who conduct their performance appraisal; $43.8 \%$ of SET assessed by the Principal; $1.9 \%$ of SET assessed by the local service; and $1.5 \%$ of SET assessed by the School Supervisor. In the case of writing a report as an evidence of SET performance, the data also varied greatly. As many as $35.8 \%$ of SET claim to make a written performance report, and $48.3 \%$ of SET are not required to make a written performance report. Unclear job demands cause the unclear performance of SET. The survey results found that only $3.76 \%$ SET admitted his work was optimal and $89.85 \%$ SET admitted his work was not optimal. Some SET also claimed to have received complaints from parents of children with special need (32\%) because they have not been able to work optimally. The above findings indicate that there is no standard of SET performance appraisal among regions.

\section{Work Award of SET}

One of the impacts of the lack of SET professional development standards is the 
various financial rewards of SET profession. Table 5 shows the financial reward data of the SET profession in inclusive schools in Indonesia.

TABLE 5. The financial rewards of SET profession in inclusive schools

\begin{tabular}{lcc}
\hline Category & Total & $\begin{array}{c}\text { Percentage } \\
(\mathbf{\%})\end{array}$ \\
\hline Very adequate & 6 & 2.26 \\
Adequate & 52 & 19.55 \\
Inadequate & 158 & 59.40 \\
Very inadequate & 49 & 18.42 \\
\hline
\end{tabular}

The table above shows that most SETs stated that the financial rewards for SET profession are in the category of inadequate $(59.40 \%)$ and very inadequate $(77.82 \%)$. Only $2.26 \%$ SET stated that the financial rewards for SET profession are in very adequate categories, while $19.55 \%$ are in adequate categories.

\section{Career Development of SET}

In terms of career development of SETs in inclusive schools, $87.55 \%$ of SETs do not have a certain employment status. SET with employment status of state employee or permanent employees have a clear career path, but non-state employee and nonpermanent employees have no clear career path. There are $83 \%$ of SET that stated that no employment career enhancement program of SET. Therefore, it can be conclude that there is not any standard of SET employment status and SET career development. Meanwhile, career development programs existing in inclusive schools include the certification of SETs, competency test of SETs, SET communication forums, and trainings/workshops/seminars. Besides, the diverse employment status of SETs is also due to the education background of SETs.

\section{Needs of SET Professional Development}

According to the problems facing SET in inclusive schools in Indonesia, professional development of SET is needed. Table 6 shows the research results related to the need for professional development of SET profession in inclusive schools in Indonesia.

TABLE 6. Professional Development Needs of SET

\begin{tabular}{lcccc}
\hline \multicolumn{1}{c}{ Type of Needs } & \multicolumn{4}{c}{ Level (\%) } \\
\cline { 2 - 5 } & $\begin{array}{l}\text { Very } \\
\text { high }\end{array}$ & High & Low & $\begin{array}{c}\text { Very } \\
\text { low }\end{array}$ \\
\hline $\begin{array}{l}\text { Competence } \\
\text { development of SET }\end{array}$ & 24.5 & 37.7 & 28.3 & 9.4 \\
\hline $\begin{array}{l}\text { Performance } \\
\text { appraisal of SET }\end{array}$ & 37.7 & 39.6 & 22.6 & 0 \\
\hline Work award of SET & 75.5 & 24.5 & 0 & 0 \\
\hline $\begin{array}{l}\text { Career development } \\
\text { of SET }\end{array}$ & 75.5 & 24.5 & 0 & 0 \\
\hline
\end{tabular}

The table 6 shows that there are four SET requirements related to SET professional development, which are SET competence development, SET performance appraisal, SET work award, and SET career development. Based on the table, it can be concluded that there is a high and very high need for professional development of SET.

\section{DISCUSSION}

The results showed that from fourdomains studied related to professional development of SET in inclusive schools (competencedevelopment, performance appraisal, work award, and career development) indicate problems to be overcome. In terms of competence development, SET has not benefited from the competencedevelopment programs by the government or the schools. The competencedevelopment programs still do not meet their needs. It shows that the forms of the competencedevelopment programs given to the SET are still more 'top-down' programs and have not been based on the results of prior assessment needs. Markelz, A., Riden, B., Scheeler, M.C. (2017) explains that the competence of SET needs to be prepared not only when teachers are still studying in universities but also through training related to teacher competence transition from university to teacher competence in-service in school, so that there is a continuity between knowledge gained from universities and knowledge in school.

In terms of performance appraisal, most SETs feel did not get performance appraisal by superiors. It shows that the SET profession has not been regarded as a demand of professional work. It was just considered as merely complying with the National Education Ministerial Regulation No. 70 of 2009 on Inclusive Education which requires that each inclusive school should be supplied at least one SET. Woolf (2014) also explains that there has been no a standard measurement of teacher performance evaluation developed for special education teachers. Therefore, it is necessary to standardize the measurement of performance evaluation of special education teachers, especially in inclusive schools.

In terms of work award, most SET get inadequate financial awards and only a few are adequately awarded according to the standard of teachers in general. According to Lawler (Conley, S. \&Odden, A., 1995), salary rewards can be based on performance, job task, or knowledge and skills of a person. Therefore, the financial award for the SET also needs a clarity standard based on those criteria so that the SET profession has a guarantee in the future. Billingsley \& Cross (1991) even explains that the issue of teacher salary for special education is one obstacle for regular teachers to teach in special education. It shows that salary rewards for special education teachers still do not provide guarantees for the future. Thus, SET professional development needs to pay attention to the SET financial rewards (Conley, S. \&Odden, A., 1995). 
In theterm of career development, SET profession also does not have clear career path. SET status in inclusive schools also lacks of clarity. It is demonstrated by the varying status of the SET, ranging from volunteers, honorary teachers, permanent teachers, or civil servants teachers. Therefore, regulation related to clarity of SET role and status in inclusive school is needed. Shepherd, K.G., Fowler, S., McCormick, J., Wilson, C. L., \& Morgan, D. (2016) also recommended the need for policies related to the clarity of the status and role of special education teachers.

Thus, it can be concluded that the SET profession in Indonesia still faces various problems. Therefore, a more professional, sustainable, and reliable SET professional development program is needed, based on the results of need assessment. In addition, the regulations of professionaldevelopment of SET are needed for the existence of SET profession in inclusive schoolsas well as the profession of teachers in general.

\section{CONCLUSION}

Based on the results and discussion, it can be concluded that the condition of the SET profession in inclusive school in Indonesia still faces many problems, such as the absence of professional development related to the competence development, performance appraisal, work award, and career development of SET. Furthermore, the level of requirement for professional development of SET tends to be high and very high, including the competence development, performance appraisal, work awards, and career development of SET.

\section{REFERENCES}

[1] Billingsley, B. S. \& Cross, L. H. (1991). "General Education Teachers' Interest in Special Education Teaching: Deterrents, Incentives, and Training Needs". Teacher Education and Special Education, 14(3): 162-168.

[2] Billingsley, B. S. (2004). "Promoting Teacher Quality and Retention in Special Education". Journal of Learning Disabilities, 37(5): 370-376.

[3] Brownell, M. T., Sindelar, P. T., Kiely, M. T., \& Danielson, L. C. (2010). "Special Education Teacher Quality and Preparation: Exposing Foundations, Constructing a New Model". Exceptional Children,76(3): 357-377.

[4] Conley, S. \&Odden, A. (1995). "Linking Teacher Compensation to Teacher Career Development". Educational Evaluation and Policy Analysis, 17(2): 219-237.

[5] Douglas, S. N., Chapin, S. E., \& Nolan, J. F. (2016). "Special Education Teachers, Experiences Supporting and Supervising Paraeducators, Implication for Special and General Eucation Settings". The Journal of Teacher Education Division of the Council for Exceeptional Children, 39(1): $60-70$.
[6] Dudzinski, M., Roszmann-Millican, M., \&Sbank, K. (2000). "Continuing Professional Development for Special Educators: Reforms and Implications for University Programs". Teacher Education and Special Education, 23(2): 109-124.

[7] Gehrke, R. S. \&Cocchiarella, M. (2013). "Preservice Special and General Educators Knowledge of Inclusive". The Journal of Teacher Education Division of the Council for Exceeptional Children, 36(3): 204-2016.

[8] Gunarhadi, Sugini, \&Andayani, T.R. (2012). "Teachers' Performance in Inclusive Education". Procedia-Asean Academic Community International Conference, HS-36PF: 48-51.

[9] Gunarhadi, Sunardi, Andayani, T.R., \& Anwar, M. (2016). "Pedagogic mapping of teacher competence in inclusive schools". Procedia International Conference of Teacher Training Education, 1(1): 389-394.

[10] Johnson, E. \&Semmelroth, C. L. (2013). "Special Education Teacher Evaluation: Why It Matters, What Makes It Challenging, and How to Address These Challenges". Assessment for Effective Intervention, 39(2): 71-82.

[11] Markelz, A., Riden, B, Scheeler, M. C. (2017). "Generalization Training in Special Education Teacher Preparation: Does It Exist?”. Teacher Education and Special Education, 40(3): 179193.

[12] McCall, Z., McHatton, P. A., \&Shealey, M. W. (2013). "Special Education Teacher Candidate Assessment: A Review". Teacher Education and Special Education, 37(1): 51-70.

[13] Ministry of National Educations. 2009. National Education Ministerial Regulation No. 70/2009 on Inclusive Education.

[14] Shepherd, K.G., Fowler, S., McCormick, J., Wilson, C. L., \& Morgan, D. (2016). "The Search for Role Clarity: Challenges and Implications for Special Education Teacher Preparation". Teacher Education and Special Education, 39(2): 83-97.

[15] Sindelar, P. T, Brownell, M. T., \& Billingsley, B. (2010). "Special Education Teacher Education Research: Current Status and Futire Directions". The Journal of Teacher Education Division of the Council for Exceeptional Children. 33(1): 8-24.

[16] Sledge, A. \&Pazey, B. L. (2013). "Measuring Teacher Effectiveness Through Meaningful Evaluation: Can Reform Models Apply to General Education and Special Education Teachers?". Teacher Education and Special Education, 36(3): 231-246.

[17] Vernon-Dotson, L. J., Floyd, L. O., Dukes, C., \&Darling, S. M. (2013). "Course Delivery: Keystones of Effective Special Education 
Teacher Preparation". Teacher Education and Special Education, 37(1): 34-50.

[18] Woolf, S. B. (2014). "Special Education Professional Standards: How Important Are
They in the Context of Teacher Performance Evaluation?". Teacher Education and Special Education, 38(4): 276-290. 